\title{
チェルノブイリに学ぶ
}

\section{Learning from Chernobyl}

Nature Vol.440(969-970)/20 April 2006

原子力発電の名を傷つけたチェルノブイリ原発事故の記憶が薄らぎつつある中で、原子力発電技術に対す る世間の支持を再び取り戻す時期がやってきた。

あの時の映像は何度もよみがえり、心にぬぐいがたく刻み 込まれている。休みなく煙を吐き出す発電所。その一方で、 ソビエト連邦の能力不足の官僚制度はいたるところで崩壊 を起こし、大混乱に陥った。1986 年 4 月 26 日にチェルノ ブイリ原子力発電所の 4 号原子炉から噴き出た放射能雲が 原因で死亡する人々の数が今後どこまで上るかは、誰にも 予想できていない。これをめぐる論争が今も続いていると いう事実こそが、事態を十分に物語っている（Nature 440, 982,993; 2006 参照)。

あれから 20 年。原子力発電は、人々の期待をじわじわと 取り戻している。原子力発電が支持を失ったのは、もちろ んチェルノブイリだけのせいではなかった。1979年に米国 ペンシルベニア州で発生したスリーマイル島事故、いくつ かの国々における景気の後退や技術的失敗の数々、そして 化石燃料が安価で入手可能なエネルギー源としての地位を 驚きの粘り腰で死守したことなどから、原子力発電に対す る不信感はチェルノブイリ事故が起きる頃にはすでに決定 的なものとなっていた。

だが、こうした事故の記憶が薄れる中で、原子力発電の意 義を復活させる要因がまたいくつか生まれてきている。エネ ルギー価格が再び高騰していること、各国政府が化石燃料排 出量を規制して気候変動に取り組もうとしていることなどで ある。カリフォルニアからカルカッタに至る世界各地のエコ ノミストは、将来のエネルギー供給に関する円グラフを見つ めながら、今後は原子力発電が一定の役割を果たす必要があ るという。だが、果たしてほんとうにそうだろうか。

その答えは、条件付きのイエスとしたい。各国政府がチェ ルノブイリの本当の教訓を学ぶことが、その条件である。 原子力発電が安全でないといっているわけではない。市民 の安全を守るための合理的な措置もとれないような、腐敗
した、無責任で放漫な姿勢の政治体制の手にある原子力発 電は危険だといっているのである。核エネルギーの未来は、 安全な原子炉の開発や地質学的に信頼性の高い核廃棄物処 理施設の建設にまずあるのではなく、原子力発電技術を安 全に運用し、管理する能力があると各国が世間の信頼を築 き上げることができるかどうかにかかっている。

\section{信頼の構築}

信頼を獲得するための方法はさまざまだ。フランスでは、高 速鉄道やコンコルド、それに独自の核抑止力をもたらした中 央集権的テクノクラシーが国民の高い評価を得ており、国内 随所に立地する原子力発電所も広く受け入れられている。ス カンジナビア諸国にはまた異なった政治的伝統があり、国民 の包括的な意思決定によって、世界初の核廃棄物永久貯蔵 施設の建設につながる道が開かれるのもまもなくかもしれな い。しかし、そのほかの国々における核エネルギーの未来は、 不透明な状態のままだ。原子力発電が世間に確実に受け入れ られるようにするための道すじが未整備なのである。

この方程式における重要な要素は、全世界で共通してい る。具体的には、原子力発電と核兵器の現実的なつながり についての認識、利用可能な発電技術、その安全性と経済性、 そして核廃棄物の再利用と処理の問題である。

最近のイランの動きからは、原子力発電と核兵器との相互 作用に関して改めて苦く思い起こされた。1950 年代に起き た「原子力の平和利用」運動の頃から、原子力発電推進派は 原子力発電と核兵器の 2 つを切り離して考えようとしてきた が、両者のつながりは密接で分けられるようなものではない。 核兵器の拡散を抑止する信頼性の高い枠組みがあれば、ヨー ロッパ、日本、米国において原子力発電に対する国民の支持 を高めるのに役立つだろう。だが、原子力発電の拡大のかげ 
に核兵器の拡散があるのだとしたら、それは悲惨な結果をも たらす可能性がある。

原子力発電所の技術は改良が重ねられている（Nature 429, 238-240; 2004 参照)。チェルノブイリで使われてい た原子炉は非常に旧式のもので、安全システム、制御方法、 管理方法とも許容できる基準を大幅に下回っていた。今日 稼動している原子炉はチェルノブイリのような事故を起こ しにくく、現在検討中の新システムによれば安全性がさら に向上する可能性もある。

しかし残念なことに、原子炉の安全設計が高まっても、 原子力発電所はテロ攻撃を受けやすいのではないかという 懸念を静める効果はほとんどない。英国下院の委員会が 4 月中旬に発表した原子力発電に懐疑的な報告書でも、この ような懸念が表明された。

\section{コスト計算}

原子力発電所の経済性については激論が交わされている (Nature 440, 984; 2006 参照)。規制緩和によって開放の進 んだ発電市場が過去 20 年の間に形成されてきたが、ランニ ングコストは低いものの建設コストが高く、また将来的なマ イナス要因が不透明という特徵をもつ原子力発電は、ほとん ぞ関心を集めてこなかった。かつては、電力の生産にかかる コストをベースとした論争が行われたが、今ではその「コス ト」という名のバケツには何が含まれるのかという、より主 観的な議論が繰り広げられている。発電所の敷地を元の状態 に戻すには莫大なコストがかかり、核廃棄物や使用済燃料の 最終処分も高コストとなる可能性がある。発電所の新規建設 には、国からの財政的な保証（英国や米国の場合）や、政府 の直接関与（インドや中国の場合）が必要となる。

そして核廃棄物の処理問題が、今でもこの業界のアキレ ス腱となっている。原子力発電を推進する政府がこれに対 する答えをもたず、使用済燃料やその他の廃棄物を地上に 放置し、その扱いを将来の世代にゆだねるなどといったこ とは、責任の放棄にほかならない。原子力発電所に対する テロ攻撃の脅威、そして使用済燃料が盗まれてテロ攻撃に 利用されるかもしれないというリスクのもと、複数の施設 で核廃棄物を長期的かつ局所的に保管するという考え方は 以前にも増して支持を受けづらくなっている。

核廃棄物処理をめぐる管理には、いろいろな方法が用いら れている。米国ネバダ州のユッカマウンテンは、その失敗を 示す高価な記念碑と化す重大な危機に直面している（Nature 440, 987; 2006、ダイジェスト本号 p.8 参照)。この土地が
選ばれたのは、ネバダ州には廃充物処理施設の選定過程から 逃れられるほどの人口密度も政治力もなかったからだった。 この絶望的で非科学的な手法が蒔いた種は今、自らの手で刚 り取る必要があるのかもしれない。その点ではスカンジナビ ア諸国の対応のほうがややすぐれている。フィンランドでは、 継続的な核エネルギープログラムが根底にあることから、核 廃棄物処理施設に対する支持が得られている。スウェーデン での支持も、核エネルギーの問題全体について考えることか できるという期待に基づくものである。フランスは処理施設 の用地選定でやや進んでおり、いつものように決然と問題に 取り組んでいくだろうという信頼がもたれている。計画を白 紙に戻さざるをえなくなた英国では、放射性廃棄物管理委 員会を使って、完全に納得のいくものではないにしろ、興味 深い市民聴聞の試みに取り組んでいる。

今後 20 年間に原子力発電所を最も多く建設することが予 想されるインドと中国は、これまでのところ核廃棄物処理に ついてほとんど言及していない。両国が環境的に責任をもっ た方法で問題に対処できるかどうかについては、時の判断を 待つほかないだろう。しかし、原子力技術は国家の威信をか けた重大な問題だと位置づけられれば、フランスの例が示唆 するように、アジアにおける原子力発電には核廃棄物処理施 設のあるなしにかかわらず確固たる未来があるだろう。

しかしながら欧米では、原子力発電がもつ将来的な選択 肢の幅は、現在の白熱した論争から示唆されるよりもかな り狭くなると考えられる。ドイツの前政権が一時的に採用し た、原子力発電の放棄という選択肢は実現しないだろう。ま た、スリーマイル島やチェルノブイリでの事故以前に構想さ れていた大規模な建設計画のようなもの（Nature 244, 392; 1973, Nature 257, 346; 1975 参照）も実現されないだろう。

むしろ各国とも、既存の原子力発電の一部を代替施設に 置き換えるか、原子力発電を緩やかなペースで拡大させる かという選択肢の間で推移する可能性が高い。地球温暖化、 エネルギーコストの高騰、石油の供給量の信頼性に対する 疑念といった事情を勘案すれば、原子力発電の緩やかな増 強のほうが推奨される。ただし、そのために再生可能エネ ルギーの研究や利用が抑制されてはならない。

核エネルギーの技術的な見事さは常に科学者や技術者の 心に訴えかけ、この半世紀の間、核エネルギーを支持する 人々のなかでも科学者や技術者の存在は極立っていた。核 エネルギーの開発を支持する人たちは、クリーンで完結し た核然料サイクルの実現を一貫して約束してきた。今こそ、 その約束が守られ、実現されたいものである。 